\title{
Małgorzata Łukianow-Tukalo
}

Polska Akademia Nauk

\section{Marcin Maciejewski}

Uniwersytet Zielonogórski

\section{Pamięć Kresowian i o Kresach w kontekście przemian pamięci na Ziemiach Zachodnich i Północnych Polski}

STRESZCZENIE $W$ artykule przeanalizowano problematykę pamięci o Kresach Wschodnich na przykładzie mieszkańców dwóch miast znajdujących się w dwóch regionach: Kwidzyna (położonego w regionie Powiśla) oraz Żar (położonych w regionie Dolnych Łużyc). Szczególnym wymiarem kształtowania tej pamięci jest nie tylko fakt, że oba miasta położone są w regionach będących częścią Ziem Zachodnich i Północnych. Tekst koncentruje się na dynamice przemian pamięci związanych z kresową narracją pamięci - zarówno tej związanej ze świadkami historii, jak i kresowej postpamięci. Żary i Kwidzyn po drugiej wojnie światowej rozwijały się inaczej. Różnice, które dla autorów są szczególnie istotne, to odmienna struktura migracji oraz rozwój i instytucjonalizacja organizacji kresowych. Można zauważyć pewne wspólne cechy rozwoju organizacji kresowych oraz ostrożnie wskazać wspólny mianownik ich działalności.

\section{SŁOWA KLUCZOWE}

ZIEMIE ZACHODNIE I PÓŁNOCNE, KRESY WSCHODNIE, KWIDZYN, ŻARY, POLE PAMIĘCI SPOŁECZNEJ 


\section{Wprowadzenie}

Pamięć o osobach, które przyjechały z Kresów Wschodnich, zajmuje ważne miejsce w polskiej pamięci narodowej, a w szczególny sposób wpisuje się w pamięć mieszkańców regionów Ziem Zachodnich i Północnych, gdzie osoby z Kresów były kierowane (w zależności od lokalnej społeczności przesiedleńcy z Kresów mogą stanowić od kilkunastu do kilkudziesięciu procent osadników). Jest to pamięć związana przede wszystkim z doświadczeniem podwójnej okupacji - zarówno hitlerowskiej, jak i sowieckiej. Istotne dla tej pamięci (zwłaszcza dawnych obywateli województw południowo-wschodnich II RP) są stosunki polsko-ukraińskie we Wschodniej Galicji i na Wołyniu, które w 1943 roku doprowadziły do masowych mordów. Ramy tej pamięci wyznacza także przymusowy charakter wyjazdu z miejsca zamieszkania.

W polu pamięci mieszkańców Ziem Zachodnich i Północnych krzyżuje się wiele narracji. Główną hipotezą prezentowanego tekstu jest to, że narracje pamięci pozostają względem siebie w określonych relacjach: mogą wzajemnie łączyć się lub wykluczać, może między nimi zachodzić relacja dominacji lub spychania narracji mniejszościowej do sfery niepamięci i forsowania innej wizji przeszłości. W niniejszym tekście autorzy przedstawiają to zjawisko na podstawie analizy narracji kresowej w dwóch wybranych regionach. Artykuł ma na celu analizę porównawczą rozwoju instytucjonalnego pamięci związanej z Kresami Wschodnimi w dwóch miastach: w Kwidzynie (województwo pomorskie, region Powiśla) oraz Żarach (województwo lubuskie, region Dolnych Łużyc).

Jako moment, w którym stało się możliwe kultywowanie tej pamięci w przestrzeni publicznej, można wskazać przełom 1989 roku oraz procesy transformacji ustrojowej. W tym okresie możliwe stało się wskazywanie na zbrodnie popełnione przez Armię Czerwoną w czasie drugiej wojny światowej (Szacka, 2000). W latach 1945-1989 główny nacisk położony był na zbrodnie dokonywane przez Niemców, a w wielu miastach powstawały pomniki wdzięczności dla „wyzwolicieli”. Wprowadzenie wolności słowa oraz możliwość przeniesienia wspomnień o tych regionach z dyskursu prywatnego do dyskursu publicznego (Orla-Bukowska, 2006) spowodowało tworzenie się organizacji mających na celu przechowywanie lub przywracanie pamięci o tych wydarzeniach. Zaczęły powstawać monografie z zakresu nauk historycznych i społecznych, których celem było opowiedzenie historii przez długi czas funkcjonujących poza obrębem dyskursu publicznego. Co więcej, w publikacjach dotyczących historii miast interesującego nas obszaru można zauważyć coraz chętniej podejmowaną problematykę odnoszącą się do trudnych i niejednokrotnie traumatycznych losów repatriantów i przesiedleńców z dawnych Kresów Rzeczypospolitej.

Ponadto same organizacje kresowe zmieniają swój charakter wraz ze zmianą pokoleniową oraz pojawianiem się nowych aktorów włączanych w doświadczenie świadków historii poprzez podział pracy mnemonicznej - aktywne prezentowanie wizji przeszłości, opowiadanie historii od nowa, tworzenie nowych instytucji pamięci oraz przypisywanie im roli (Margalit, 2004, s. 51-52). W związku z tym organizacje kresowe nie zrzeszają już wyłącznie osób doświadczających bezpośrednio w biografii przesiedlenia z terytoriów, jakie po 1939 roku nie wróciły już w granice Rzeczypospolitej. W szeregach tych organizacji pojawia się coraz więcej osób zainteresowanych kulturą kresową, które usłyszały o przesiedleniach od członków rodziny, na przykład dziadków, i chcą pogłębić swoją wiedzę na ten temat, często też odszukać dalszych przodków. Dodatkową siłą, która powoduje zaangażowanie osób niebędących świadkami danych wydarzeń, jest przekaz emocjonalny. Jak wskazuje Francesca Cappelletto (2003), odczuwanie emocji związanych z danymi 
wydarzeniami z przeszłości niekoniecznie oznacza pamiętanie o nich. Czynnikiem łączącym świadków wydarzeń oraz inne osoby jest emocjonalne znaczenie wydarzenia, niekoniecznie jego przeżycie (s. 256).

Dobór miast do analizy oparto na zasadzie kontrastu ze względu na cechy społeczne oraz charakter powojennych migracji, zachowując podobieństwa pod względem wielkości miast. Według typologii populacji mieszkańców Ziem Zachodnich opracowanej przez Leszka Kosińskiego zbiorowości tych ziem można podzielić na cztery typy:

typ I: dominuje jedna grupa ludności napływowej (około 60\% i więcej), pozostałe grupy stanowią poniżej 20\%;

typ II: istnieją dwie grupy dominujące ludności napływowej, stanowiące odpowiednio 40-60\% i 20-40\%, pozostałe poniżej 20\%;

typ III: grupa dominująca stanowi 40-60\%, pozostałe poniżej 20\%;

typ IV: dwie lub trzy grupy stanowią 20-40\%, inne poniżej 20\%, charakterystyczny dla terenów granicznych (1960, s. 110-112).

Odwołując się do wyżej wspomnianej typologii powojennych migracji na Ziemie Zachodnie, należy stwierdzić, że region Dolnych Łużyc, w którym znajdują się Żary, należy do typu III. Powiśle, w którym znajduje się Kwidzyn, należy do typu II. Przedmiotem szczególnej uwagi jest tutaj odsetek ludności, która została przesiedlona z tzw. Kresów Wschodnich. W Kwidzynie osoby te stanowiły około 20\% ogółu ludności napływowej (grupę dominującą stanowiły osoby przybyłe w ramach migracji wewnętrznych), podczas gdy w Żarach ludność z Kresów stanowi grupę dominującą około 50\% ogółu ludności.

\section{Aktorzy w polu pamięci}

Narracja kresowa funkcjonuje w odniesieniu do innych relacji pamięci - może być z nimi skonfliktowana, może być przez nie zsyłana w obszar społecznej niepamięci, może także sama przesłaniać inne wizje przeszłości. Istotne jest jednak stwierdzenie, że na treść kresowej narracji o przeszłości ma wpływ nie tylko doświadczenie i pamięć świadków, lecz także to, w jaki sposób rozwijają się inne wizje przeszłości - zarówno na gruncie prywatnym, jak i publicznym. Są to przede wszystkim narracje, które odwołują się do powojennej historii tych terenów i związane są z grupami osadników, którzy przybywali do danego regionu lub miasta (zob. Osękowski, 1994; Sakson, 1996; Traba, 2003; Osękowski, 2006; Nowosielska-Sobel, 2011).

Hipoteza dotycząca wzajemnego oddziaływania na siebie różnych wizji przeszłości została zaczerpnięta z koncepcji pola pamięci społecznej opracowanej przez Annę Sawisz (1990, s. 126-129). Sawisz dokonała teoretycznego przeniesienia teorii pola Pierre’a Bourdieu (2005) na grunt badań nad pamięcią zbiorową. Najważniejszym elementem tej koncepcji jest układ, w którym pozostają aktorzy pola. W polu nieustannie trwa „walka” o pozycję, ponieważ - w przypadku pola pamięci - aktor, który osiągnie najwyższą pozycję, ma możliwość zdefiniowania zbiorowej przeszłości oraz dystrybucji swojej wizji. One z kolei wpływają na formułowanie ram tożsamości zbiorowej (lokalnej, narodowej). Zdaniem autorów, aktorami w polu pamięci społecznej na Ziemiach Zachodnich i Północnych są jednostki, które odpowiadają za dystrybucję treści. Są to osoby, które mają osobiste wspomnienia, epizody biografii i w ten sposób narrację tworzą. Co warte podkreślenia, również są to instytucje, które tę pamięć przetwarzają i prezentują szerszemu gronu odbiorców, czyli 
organizują wydarzenia, upamiętniają, stawiają pomniki. Mogą to być także wszystkie osoby, które w tym przypadku są zainteresowane tematem Kresów Wschodnich. Warto jednak dodać, że z punktu widzenia niniejszego artykułu najważniejsze są instytucje oraz ich działalność - to, w jaki sposób te przedsięwzięcia kształtują określoną wizję przeszłości.

Dla regionów, których tożsamość jest labilna i niejednoznaczna - jak w przypadku Powiśla oraz Dolnych Łużyc - relacja pomiędzy aktorami pola jest ważna, by pomóc budować swoją tożsamość. Jednak wcześniej zachodzi inny istotny proces, którym jest określenie obrazu zbiorowej przeszłości. W niniejszym tekście autorzy mniej miejsca poświęcają analizie samej treści narracji. Z punktu widzenia tekstu ważne jest obserwowanie zmian instytucjonalnych oraz opis działań podejmowanych we współpracy z innymi podmiotami i w jaki sposób wpływa to na prezentowaną wizję przeszłości.

\section{Pamięć o Kresach i Kresowianach w Żarach}

Żary położone są w południowo-zachodniej części województwa lubuskiego. Ten fragment tzw. Ziem Zachodnich (w przeciwieństwie np. do Zachodniopomorskiego) nie stanowił odrębnego historycznie obszaru. Pamięć i tożsamość społeczna są tu kreowane nieco inaczej niż w pozostałych regionach. Dość wyraźnie widać większą identyfikację ze wspólnotami lokalnymi niż z regionem (Smolarkiewicz, 2014), a nawet fragmentaryzację tożsamości regionalnej (Mazur, 2003, s. 25). Nie powinno to zaskakiwać. Mimo przypadającego w 2017 roku osiemnastolecia istnienia województwa lubuskiego toczący się od kilku dziesięcioleci spór o samą jego nazwę nie stracił na intensywności. Położenie Żar na Dolnych Łużycach sprawia, że znajdują się one na peryferiach tego sporu. Należy przypuszczać, że proponowane przez środowiska naukowe nazwy pogłębiają dezintegracje tego administracyjnego tworu. Przykładowo określenie „Śląsk Lubuski” (Czarnuch, 2001; Toczewski, 2001) adekwatne jest z punktu widzenia geografii historycznej tylko dla kilku powiatów na południowym wschodzie województwa.

Społeczność Żar po 1945 roku stanowią w przeważającej liczbie osadnicy z Kresów. Wart podkreślenia jest fakt, że Kresowianie są grupą heterogeniczną, której zróżnicowanie polega na pochodzeniu z regionów o odmiennych obyczajach, dialektach, kulturze i historii. W przypadku Żar zdecydowanie dominującą grupą są Kresowianie z województw tarnopolskiego, wołyńskiego, Iwowskiego i stanisławowskiego.

Od końca lat 90. XX wieku w Żarach można zaobserwować powrót do historii pionierów, uwage zwraca aktywność organizacji kresowych w mieście, do których należą: Kresowe Towarzystwo Turystyczno-Krajoznawcze im. Orląt Lwowskich (dalej KTTK), Zarząd Wojewódzki Związku Polskich Żołnierzy Samoobrony Kresów II RP, Wspólnota Polska, Towarzystwo Miłośników Lwowa i Kresów Południowo-Wschodnich, Stowarzyszenie Upamiętniania Ofiar Zbrodni Ukraińskich Nacjonalistów, Związek Sybiraków.

KTTK jest jedną z najprężniej działających organizacji kresowych na zachodzie kraju. Z tego względu skupimy na niej naszą uwagę. Powstała w 2006 roku, choć zalążkiem był założony w 2003 roku Klub Tarnopolan przy Polskim Towarzystwie Turystyczno-Krajoznawczym. KTTK prowadzi własną Galerię i Bibliotekę Kresową, Dom Kultury Kresowej „Biały Orzeł” oraz Muzeum Kresowe im. ks. abpa Ignacego Tokarczuka. Jest organizatorem kilkudziesięciu wydarzeń o zasięgu lokalnym i ponadregionalnym.

Jednym z głównych celów towarzystwa jest kultywowanie pamięci o Kresach. Ma to miejsce w wielu formach, na przykład w działalności kulturalno-oświatowej, to jest organizowaniu cyklicznie: Międzyszkolnych Sejmików Krajoznawczych o Wybitnych Polakach 
Kresowych, Powiatowych Młodzieżowych Konkursów Recytatorskich Poezji Kresowej, Wojewódzkich Konkursów Krajoznawczych dla Młodzieży „Poznajemy Ojcowiznę Kresową i Budujemy Makiety Zabytków Kresowych”, Sejmików Krajoznawczych o dziedzictwie kulturowym Polaków Kresowych czy najsłynniejszych - Ogólnopolskich Festiwali Polszczyzny i Pieśni Kresowej „Wielkie Bałakanie”. Ponadto w każdy drugi czwartek miesiąca organizowane są Wieczory Pieśni i Poezji Kresowej w siedzibie Domu Kultury Kresowej przy ulicy Bohaterów Getta 22b.

Towarzystwo tylko w 2016 roku upamiętniło takie wydarzenia, jak 76. rocznica rozpoczecia masowych wywózek blisko 2 mln Polaków do ZSRR, 76. rocznica zbrodni katyńskiej i 6. rocznica katastrofy smoleńskiej, 72. rocznica akcji „Burza” i „Ostra Brama” AK na Kresach i Powstania Warszawskiego, 96. rocznica Cudu nad Wisłą, 98. rocznica powstania Orląt Lwowskich, Światowy Dzień Ofiar Ludobójstwa ONZ oraz IV Wojewódzki Dzień Pamięci o Ofiarach Ludobójstwa OUN-UPA na Polakach Kresowych, 225. rocznica pierwszej w Europie Konstytucji 3 Maja i 1050-lecie Państwa Polskiego, ponadto 70. rocznica osadnictwa wygnańców kresowych na Łużycach i Ziemi Lubuskiej połączona z 70. rocznicą zwycięstwa w drugiej wojnie światowej w Europie.

Żary mają dość bogate tradycje wojskowe, do 2001 roku stacjonowały tu oddziały wojsk lądowych, część z nich przeformowano do leżącego niedaleko Żagania. KTTK łączy je oraz wplata w narrację o Kresach, głównie poprzez podtrzymywanie tradycji i pamięci o II Armii Wojska Polskiego. Wynika to z faktu, że znaczna część repatriantów w mieście to osadnicy wojskowi. Jak opisuje Czesław Osękowski:

Duża część żołnierzy, potencjalnych kandydatów na osadnictwo wojskowe, mieszkała przed wojną za Bugiem. Władze obawiały się ich reakcji, stąd pierwszeństwo przed innymi osadnikami w wyborze miejsca do osiedlenia się. Większość zdemobilizowanych żołnierzy wiedziała, że nie ma innego wyjścia i musi zamieszkać w powiatach osadnictwa wojskowego [w tym w powiecie żarskim - przyp. M.Ł.-T., M.M.] (1993, s. 63).

Przykładowo 28 kwietnia 2016 roku zorganizowano XI Ogólnopolski Rajd Samochodowy po Łużycach „Szlakiem Bitew, Pomników, Cmentarzy Kresowych Żołnierzy II Armii Wojska Polskiego" w 71. rocznicę bitwy pod Budziszynem. Wspomniane wyżej działania, jak również te wcześniejsze oraz zaangażowanie członków KTTK w sprawy lokalne, doprowadziły między innymi do dodania członu „Kresowy” do nazwy 105. Szpitalowi Wojskowemu w Żarach „dla podkreślenia więzi łączących żołnierzy i pracowników wojska 105. Szpitala Wojskowego z Przychodnią Samodzielnego Publicznego Zakładu Opieki Zdrowotnej w Żarach z rodakami, którzy zostali repatriowani z Kresów Wschodnich Drugiej Rzeczypospolitej i osiedlili się na terenie Gminy Żary" (MON, 2014). KTTK podejmuje działania związane z Cmentarzem Łyczakowskim. Aktywnie wspiera akcję „Światełko Pamięci dla Łyczakowa" polegającą na zbiórce zniczy mających zapłonąć 1 listopada na Iwowskich nekropoliach (dotychczas 5 edycji).

Od kilku lat można zauważyć znaczną aktywność KTTK w dyskursie publicznym. Wymownym przykładem jest akcja „Oddajcie Orlętom Lwy” lub prośba o wszczęcie procedury odebrania Krzyża Kawalerskiego Orderu Odrodzenia Polski nadanemu Piotrowi Tymie, przewodniczącemu Związku Ukraińców w Polsce (Myśl Polska, 2015). Towarzystwo kieruje apele do najwyższych władz państwowych, które upublicznia wraz z odpowiedziami na swojej stronie internetowej. Co więcej, pisma kierowane do instytucji rządowych 
sygnowane są podpisami środowisk kresowych z całej Polski, jak choćby Patriotyczny Związek Organizacji Kresowych i Kombatanckich w Warszawie, Stowarzyszenie Kresowian Ziemi Dzierżoniowskiej, Związek Kombatantów RP i Byłych Więźniów Politycznych, Instytut Kresów Rzeczypospolitej, Stowarzyszenie Upamiętniania Polaków Pomordowanych na Wołyniu w Zamościu, Stowarzyszenie Kresowian Kędzierzyn-Koźle, Światowy Kongres Kresowian i wiele innych.

Działalność Towarzystwa widoczna jest także w przestrzeni miejskiej. Pomniki związane z dziejami Kresów znajdują się w kilku częściach miasta. Towarzystwo jest inicjatorem budowy pomników Wygnańców Kresowych w Żarach oraz Lipinkach Łużyckich i Jasieniu; pomnika Żołnierza Polskiego z Kresów w Żarach. W 2013 roku odsłonięto kamienną tablicę Pamięci Kresowych Komendantów 105. Kresowego Szpitala Wojskowego w Żarach. Wraz ze Związkiem Sybiraków KTTK zainicjowało powstanie pomnika Zesłańców Sybiru. Także katastrofę smoleńską, w jej pierwszą rocznicę, upamiętniono odpowiednią tablicą. Na terenie 105. szpitala znajduje się tablica pamięci ku czci dr. płk. Kazimierza Maciejewskiego z Grodna (obok której posadzono dąb katyński jego imienia) oraz tablica Pamięci Pomordowanych przez NKWD Oficerów-Lekarzy ze Szpitali Polowych z Grodna i Brześcia nad Bugiem. (Posadzono też dęby: Dąb katyński im. płk. Stanisława Z. Widackiego - prezydenta Tarnopola, Dąb Jana Zygmunta Rumla i Dąb Traugutta - obok tego ostatniego znajduje się tablica Pamięci Powstania Styczniowego). Najsłynniejszym chyba przedsięwzięciem Towarzystwa jest wmurowanie w obrębie murów miejskich przy ulicy Podwale w 2015 roku tablicy: „Ku czci sprawiedliwych Ukraińców pomordowanych przez zbrodniczą Ukraińską Powstańczą Armię za pomoc okazaną ofiarom banderowskiego ludobójstwa".

Te nieodległe wydarzenia historii upamiętniane tak chętnie w mieście pokazują, że pewna część pierwszego pokolenia Polaków, którzy urodzili się w Żarach, tkwi mentalnie zakorzeniona w przestrzeni pamięci Kresów Rzeczypospolitej (Maciejewski, 2016, s. 198).

Doświadczenia przybyłych tu Kresowiaków, oderwanie od miejsca urodzenia, brak ojcowizny/ojczyzny okazały się pomocne w podtrzymywaniu tzw. zastanego dziedzictwa w rejonie Żar, w tym wypadku łużyckiego. Towarzystwo przyłączyło się do organizowanych w 2016 roku VI Dni Kultury Serbołużyckiej z hasłem: „Kresowianie chronią dziedzictwo kulturowe Serbołużyczan". Interesujący wydaje się pogląd Beaty Halickiej (2015), która zauważa, że Kresowianie jako mieszkańcy pogranicza: „Do momentu wygnania żyli w bezpośrednim sąsiedztwie ludności ukraińskiej, białoruskiej, litewskiej i żydowskiej. Skutkiem tego wykształcili bardzo silną świadomość narodową oraz przywykli do wyjątkowo pieczołowitego podtrzymywania własnej kultury oraz obrony swojej odrębności” (s. 344). Zastanawiające jest, czy angażowanie się w tę działalność jest wynikiem faktu, że Kresowianie czują wspólnotę losu z Łużyczanami (podobnie jak oni wypędzonymi), czy jest im ona po prostu bliższa od niemieckiej. Kresowianie żarscy wywodzący się w znacznej liczbie z kresów południowo-wschodnich ciągle szukają przestrzeni do dialogu oraz dopominają się poszanowania trudnej historii relacji polsko-ukraińskich i godnego jej upamiętniania. Przede wszystkim dotyczy to uznania krwawych wydarzeń na Wołyniu w 1943 roku jako ludobójstwa - na ten temat spór toczy się nie tylko na poziomie lokalnych narracji pamięci, lecz także na poziomie szerszej, polsko-ukraińskiej debaty. Duże zaangażowanie w liczne przedsięwzięcia organizowane lub współorganizowane, wspierane przez Towarzystwo podtrzymują pamięć o przeszłości znacznej części jego mieszkańców, jak również popularyzuje polską kulturę kresową. 


\section{Pamięć o Kresach i Kresowianach w Kwidzynie}

Podobnie jak Żary region Powiśla, w którym znajduje się Kwidzyn, nie miał historycznie usankcjonowanych granic. Do 1945 roku zlokalizowany był w Prusach Wschodnich. Po 1945 roku i po przyłączeniu wschodnich prowincji Niemiec do Polski znajdował się w województwie elbląskim, a po reformie terytorialnej - w pomorskim (obecnie). Zmiany przynależności terytorialnej oraz administracyjnej miały istotny wpływ na tworzenie się tożsamości regionalnej. Brak jest także jednolitej nazwy opisującej region. Można odnaleźć informację o tym, że Kwidzyn to część Warmii, Dolne Powiśle lub po prostu Powiśle. Konsekwencją tych zmian jest fakt, że mieszkańcy z trudem mogą zdefiniować położenie swojego regionu oraz jego granice (Ciechorska-Kulesza, 2013, s. 101-102). Po raz pierwszy nazwa Powiśle pojawiła się przy okazji plebiscytu w 1920 roku, nazywanego plebiscytem na Warmii i Mazurach lub plebiscytem na Warmii, Mazurach i Powiślu. Nazwę stworzył Związek Polaków w Niemczech na potrzeby organizacji plebiscytu.

W Kwidzynie istnieją obecnie dwie organizacje, które kultywują pamięć o mieszkańcach tzw. Kresów Wschodnich II RP. Pierwsza z nich to Kwidzyńskie Koło Sybiraków (KKS). Koło powstało w 1990 roku, a więc stosunkowo wcześnie po upadku komunizmu. Początkowo zrzeszało tylko osoby, które bezpośrednio doświadczyły wywózki na Syberię, raczej nie przyjmując w swoje szeregi innych osób, na przykład miłośników historii. Działa przede wszystkim na rzecz kultywowania pamięci o sybirakach. Przykładem tej działalności jest utworzenie osiedla oraz ulicy Sybiraków w Kwidzynie. Ponadto w ramach tego osiedla utworzono ulicę Zdzisławy Smodlibowskiej - nauczycielki w kwidzyńskim Liceum Pedagogicznym, sybiraczki, która zachowała się w pamięci wielu mieszkańców miasta. Osobom deportowanym na Syberię poświęcona jest też pamiątkowa tablica znajdująca się w kwidzyńskiej katedrze. Została odsłonięta w 1995 roku.

Działalność KKS to przede wszystkim uczestnictwo w rocznicach oraz upamiętnieniach i przygotowanie pocztów sztandarowych (np. 11 listopada, 3 maja), również spotkania opłatkowe oraz kultywowanie pamięci poprzez spotkania, podczas których uczestnicy wymieniają się wspomnieniami. W przypadku KKS dominuje zdecydowanie rodzinna transmisja pamięci o przeszłości, która po wielu latach wyciszania po 1945 roku teraz uzyskała możliwość funkcjonowania publicznie. Koło gromadzi także wspomnienia kwidzyńskich sybiraków na swojej stronie internetowej. Znajdują się na niej między innymi wspomnienia Anny Szafałowicz, która pisze w sposób następujący:

Do Polski powróciliśmy z Zudiłowa 4 lipca 1946 roku. Przez dwa tygodnie przebywaliśmy w punkcie rozdzielczym w Gostyninie, skąd trafiliśmy do zorganizowanego dla nas sierot z zesłania, Dom [Domu przyp. red.] Dziecka nr 2 w Kwidzynie. Trójka mojego młodszego rodzeństwa, ze względu na jej zły stan zdrowia, bezpośrednio z Gostynina trafiła na leczenie do Sanatorium w Rabsztnie [Rabsztynie - przyp. red.]. Po półrocznym pobycie i kuracji w sanatorium przewieziono ich do Kwidzyna, gdzie znów stanowiliśmy jedną zgraną rodzinę. Od tamtej pory minęło już wiele lat. Wszyscy już dawno prowadzimy samodzielne życie. Pozakładaliśmy własne rodziny, jesteśmy już babciami i dziadkami. Pomimo że mieszkamy w różnych miejscach, często spotykamy się przy różnych okazjach. Czujemy się jak jedna wielka i kochająca się rodzina. Tragiczna przeszłość scementowały nas i staramy się wpoić wyznawane przez nas wartości naszym dzieciom i wnukom (Szafałowicz, b.d.).

Zupełnie inaczej wygląda z kolei działalność Stowarzyszenia Kresowiaków w Kwidzynie (SKK), które powstało w 2015 roku. Jest to organizacja (zarejestrowana jako pozarządowa), 
która oprócz kultywowania pamięci o Kresach włącza się w szerszą działalność publiczną i współpracuje z innymi organizacjami, tworząc swoistą sieć w lokalnej przestrzeni publicznej. Współpracuje z takimi organizacjami, jak Obóz Narodowo-Radykalny, Klub Gazety Polskiej, Towarzystwo Miłośników Wilna i Ziemi Wileńskiej, a także kwidzyńską szkołą katolicką. Stowarzyszenie urządza spotkania w ramach tzw. Akademii Człowieka Myślącego, wspiera również organizację mszy w rycie trydenckim w Kwidzynie.

Co szczególnie istotne, do SKK przynależą nie tylko osoby, które bezpośrednio doświadczyły powojennych przesiedleń, lecz także takie, które określają swoje korzenie jako kresowe lub są po prostu zainteresowane tematem. Jak wskazuje przewodniczący SKK:

Członkami kwidzyńskiego Stowarzyszenia Kresowiaków są potomkowie osób z Wileńszczyzny, Grodzieńszczyzny, Podola, Polesia, Lwowa, Wołkowyska, Wołynia i innych części Kresów Wschodnich Rzeczypospolitej, którzy bestialsko wygnani przez sowietów ze swoich domostw, przybywali do Kwidzyna i powiatu zaraz po wojnie. Są także te, które przybyły znacznie później, a którym Kresy, ziemia ich przodków jest nadal bardzo bliska (Kosiński, 2015).

\section{Różne pamięci - różne działania}

Największą różnicę pomiędzy pamięcią o Kresach w Kwidzynie i Żarach stanowi dynamika działań podejmowanych przez organizacje kresowe po 2000 roku, a w szczególności w latach 2014-2015. Lata 90., a zwłaszcza ich początek, z punktu widzenia pamięci o Kresach to przede wszystkim czas, gdy narracje te przedostawały się do strefy publicznej. Przed 1989 rokiem kresowa narracja pamięci dominowała w sferze prywatnej. W latach 90. tworzyły się organizacje - jak przykładowo Kwidzyńskie Koło Sybiraków - które działania koncentrowało przede wszystkim na tym, by temat deportacji na Syberię, a w tym Kresów, obecny był w szerszym dyskursie. Tymczasem obecność tematyki kresowej zmieniła swój charakter kilkanaście lat później. Jej priorytetem nie było już zaistnienie publicznie jako takie, ale pozycja. Widać to na przykładzie KTTK w Żarach; w notce umieszczonej na stronie internetowej „11 listopada Święto Niepodległości” czytamy:

Miło nam poinformować, że Prezydent RP Andrzej Duda wystosował zaproszenie na oficjalne uroczystości Święta Niepodległości w dniu 11 listopada w Warszawie dla Prezesa Kresowego Towarzystwa TurystycznoKrajoznawczego im. Orląt Lwowskich w Żarach. Jest to niewątpliwie wyraz szacunku i uznania dla wieloletniej ciężkiej i owocnej pracy na rzecz krzewienia wartości patriotycznych Prezesa Józefa Tarniowego, jak i kierowanej przez niego organizacji. Mamy nadzieję, że akt zaproszenia naszego Prezesa jest zwiastunem przyszłej owocnej współpracy Kancelarii Prezydenta ze środowiskami kresowymi. Jesteśmy wdzięczni, że w tak ważnym dniu Prezydent nie zapomniał o Kresowym Towarzystwie Turystyczno-Krajoznawczym im. Orląt Lwowskich, które od lat buduje wartości patriotyczne w naszym regionie (KTTK, 2015).

W tym punkcie warto wrócić do wspomnianej wcześniej teorii pola pamięci społecznej. W polu, które jest niezależnym wycinkiem rzeczywistości społecznej, rozgrywa się walka o dominację. Przeszłość ma charakter sakralizujący, umożliwia wyznaczanie wzorów zachowań i akceptowanych wartości. Dlatego dążenie do tego, by uprawomocnić swoją wizję przeszłości, jest tak ważne, daje bowiem możliwość wskazywania „przynależących” i „wykluczonych" do danej wspólnoty (Sawisz, 1990, s. 128).

Choć na potrzeby teoretycznej konceptualizacji można wyróżnić różne pola (Bourdieu w swoich licznych pracach wyróżnia m.in. pole polityki, pole sztuki, pole religii i inne), w rzeczywistości różne pola mogą się przenikać. Trudno jednak zrozumieć zachodzące procesy 
przemian pamięci bez wyodrębnienia pola pamięci jako oddzielnego od innych pól, mimo że jest to stosunkowo względna autonomia. I tak, pole pamięci społecznej, w którym dominacja oznacza możliwość uprawomocnienia swojej wizji przeszłości, może być zależne od pola władzy, czyli sytuacji, kiedy aktorzy sprawujący władzę polityczną mają przemożny wpływ na to, co społeczeństwo pamięta. Jak wskazuje Anna Sawisz, ze względu na historyczny charakter pól dla jednych czas pracował na ich korzyść, co jest dodatkowym źródłem wyjściowych nierówności (1990, s. 129). Jeśli spojrzeć na narrację kresową, nietrudno uświadomić sobie, jakie wyjściowe nierówności można zauważyć. Przede wszystkim dotyczy to sytuacji okresu PRL, a w szczególności czasu krótko po zakończeniu wojny, kiedy bezpośredni świadkowie historii nie mieli możliwości dystrybuowania swojej wizji przeszłości. Zupełnie inaczej jednak wygląda sytuacja w polu pamięci, kiedy zwłaszcza po 2000 roku widać instytucjonalizację narracji kresowej w interesujących autorów miejscowościach, która skupia już nie tylko indywidualne osoby oraz ich doświadczenia biograficzne, lecz także inne instytucje, w tym polityczne i społeczne.

Przykład stanowi Stowarzyszenie Kresowiaków w Kwidzynie. Jego działalność nie skupia się jedynie na tematyce przesiedleń, ale zatacza szersze kręgi, między innymi współpracuje ono z Klubem Gazety Polskiej oraz organizuje msze trydenckie. Aktywność ta zwiększa oddziaływanie na lokalną społeczność poprzez wykorzystanie elementów pamięci społecznej, co więcej - przenosi sakralizujący charakter przeszłości na szerszy katalog wartości i idei politycznych. W przypadku Żar związane jest to z aktywną działalnością społeczną: prowadzeniem bibliotek, organizowaniem wydarzeń, upamiętnieniem w postaci tablic i pomników. Oprócz tego żarskie Kresowe Towarzystwo Turystyczno-Krajoznawcze bierze aktywny udział w komentowaniu oraz zajmowaniu stanowiska wobec bieżących wydarzeń politycznych.

Zjawisko to dobrze wyjaśnia pojęcie postpamięci opisane przez Marianne Hirsch (2014). Postpamięć pojawia się, gdy wspomnienia świadków wykraczają poza krąg transmisji rodzinnej. Pojawia się, gdy późniejsze pokolenia (distant contemporary witnesses) podejmują na poziomie osobistym, zbiorowym oraz kulturowym traumę innych, która znana im jest z opowieści, obrazów czy zachowań (s. 335). Można pokusić się także o inne stwierdzenie, że działalność organizacji kresowych w obu miastach wpisuje się w szeroki nurt wartości narodowych i mocno się w nim zakorzenia. Interesujące jest także to, że działalność instytucji odpowiedzialnych za kultywowanie pamięci o Kresach wychodzi poza różne formy upamiętnienia i wpisuje się również w nurt polityczny, komentując nie tylko wydarzenia z przeszłości, lecz także wydarzenia teraźniejsze. Umacniać tę pozycję zdają się silne przywiązanie do religii oraz ścisła współpraca z tych środowisk z Kościołem rzymskokatolickim.

\section{Podsumowanie}

Czy w tym kontekście można wnioskować na temat szerszego kontekstu pamięci Ziem Zachodnich i Północnych? Z pewnością byłyby to wnioski wstępne lub raczej punkt wyjścia do dalszych rozważań. Warto jednak przyjrzeć się procesom zachodzącym w tym specyficznym polu pamięci. O jego specyfice decyduje wiele czynników. Przede wszystkim mamy do czynienia ze zróżnicowanym charakterem migracji, dobrowolnym, przymusowym lub z ludnością autochtoniczną (polską i niemiecką). Ponadto dokonuje się zmiana pokoleniowa. W tym przypadku należy mówić o postpamięci, która nie wynika z bezpośrednich doświadczeń - doświadczeń wojny oraz migracji. Analiza rozwoju instytucji, które zajmują się narracją kresową, może stanowić jednak przyczynek do dalszych analiz, obejmujących 
inne narracje pamięci lub ukazujących przekrój przez całe pole pamięci w danej społeczności lokalnej lub regionalnej.

\section{LITERATURA}

Bourdieu, P. (2005). Dystynkcja. Społeczna krytyka władzy sądzenia. Warszawa: Wydawnictwo Naukowe Scholar.

Cappelletto, F. (2003). Long-term memory of extreme events: from autobiography to history. Journal of the Royal Anthropological Institute, 9, 241-260.

Ciechorska-Kulesza, K. (2013). Regiony zadane, wyobrażone, nienazwane, nieuchwytne. Plastyczność przestrzeni na przykładzie Żuław Wiślanych, Mierzei Wiślanej, Powiśla i okolic. Nasze Pomorze, 15, 93-107.

Czarnuch, Z. (2001). Śląsk Lubuski jako początek intelektualnej przygody. Museion. Informator Muzeum Ziemi Lubuskiej w Zielonej Górze, 10, 3-4.

Halicka, B. (2015). Polski Dziki Zachód. Przymusowe migracje i kulturowe oswajanie Nadodrza 1945-1948. Kraków: Universitas.

Hirsch, M. (2014). Generation of Postmemory: Writing and Visual Culture After the Holocaust. New York: Columbia University Press.

Kosiński, A. (2015). W Kwidzynie powstało stowarzyszenie Kresowiaków. Pobrano z: http://www. kwidzyn.naszemiasto.pl (16.12.2016).

Kosiński, L. (1960). Pochodzenie terytorialne ludności Ziem Zachodnich. Dokumentacja geograficzna. Warszawa: Wydawnictwo Polskiej Akademii Nauk.

KTTK (2015). 11 listopada Święto Niepodległości. Kresowe Towarzystwo Turystyczno-Krajoznawcze im. Orląt Lwowskich w Żarach, 9 listopada. Pobrano z: http://www.kttk.pl/index.php/ archiwum/70-11-listopada-swieto-niepodleglosci (20.12.2016).

Maciejewski, M. (2016). Dziedzictwo historyczne i kulturowe Żar w perspektywie powojennego siedemdziesięciolecia. W: A. Barska, K. Biskupska, I. Sobieraj (red.), Przestrzenie pamięci. Świat wartości w przekazie kulturowym (s. 191-202). Opole: Wydawnictwo Uniwersytetu Opolskiego.

Margalit, A. (2004). The Ethics of Memory. Cambridge-London: Harvard University Press.

Mazur, Z. (2003). Muzea a tożsamość lokalna na Środkowym Nadodrzu. Siedlisko, 1, 25-28.

MON (2014). Decyzja nr 398/MON Ministra Obrony Narodowej z dnia 2 października 2014 r. w sprawie nadania nazwy wyróżniającej „Kresowy” 105. Szpitalowi Wojskowemu z Przychodnią Samodzielnemu Publicznemu Zakładowi Opieki Zdrowotnej w Żarach.

Myśl Polska (2015). Odebrać polskie odznaczenie Piotrowi Tymie. Pobrano z: http://www.mysl-polska.pl/590 (18.12.2016).

Nowosielska-Sobel, J. (2011). „Oswajanie krajobrazu” na Dolnym Śląsku w drugiej połowie lat 40. XX wieku. W: W. Kucharski, G. Strauchold (red.), Ziemie Zachodnie - historia i perspektywy (s. 47-61). Wrocław: Ośrodek „Pamięć i Przyszłość”.

Orla-Bukowska, A.M. (2006). New Threads On an Old Loom: National Memory and Social Identity in Postwar and Post-Communist Poland. W: C. Fogu, W. Kansteiner, R. Lebow (red.), The Politics of Memory in Postwar Europe (s. 177-209). London: Duke University Press. 
Osękowski, C. (1993). Oficjalne i faktyczne cele osadnictwa wojskowego na pograniczu polsko-niemieckim po drugiej wojnie światowej. Słupskie Studia Historyczne, 3, 53-66.

Osękowski, C. (1994). Społeczeństwo Polski zachodniej i północnej w latach 1945-1956. Procesy integracji i dezintegracji. Zielona Góra: Wydawnictwo Wyższej Szkoły Pedagogicznej.

Osękowski, C. (2006). Ziemie Odzyskane w latach 1945-2005. Społeczeństwo, władza, gospodarka. Zielona Góra: Oficyna Wydawnicza Uniwersytetu Zielonogórskiego.

Sakson, A. (1996). Pomorze - trudna Ojczyzna? Kształtowanie się nowej tożsamości, 19451995. Poznań: Wydawnictwo Instytutu Zachodniego.

Sawisz, A. (1990). Transmisja pamięci przeszłości. W: A. Sawisz, B. Szacka, Czas przeszły i pamięć społeczna (s. 121-137). Warszawa: Wydawnictwa Uniwersytetu Warszawskiego.

Smolarkiewicz, E. (2014). Tożsamość terytorialna mieszkańców Ziemi Lubuskiej. W: T. Nodzyński, M. Tureczek, J. Zięba (red.), Ziemia Lubuska. Rozważania o historii i tożsamości regionu (s. 151-167). Zielona Góra: Polskie Towarzystwo Historyczne, Oddział w Zielonej Górze.

Szacka, B. (2000). Pamięć zbiorowa i wojna. Przegląd Socjologiczny, 2 (49), 11-28.

Szafałowicz, A. (b.d.). Witaj nam Polsko! Wspomnienia Anny Szafałowicz z domu Jatkowskiej. Sybiracy. Pobrano z: http://www.sybiracy2010.sybiracy.pl/wspomnienia/00004.html (16.12.2016).

Toczewski, A. (2001). Tożsamość Śląska Lubuskiego. Museion. Informator Muzeum Ziemi Lubuskiej w Zielonej Górze, 8, 1-2.

Traba, R. (2003). Kraina Tysiąca Granic. Szkic o historii pamięci. Olsztyn: Wspólnota Kulturowa Borussia.

\section{THE MEMORY OF EASTERN BORDERLANDS AND OF THEIR FORMER INHABITANTS IN THE CONTEXT OF MEMORY TRANSFORMATIONS IN POLISH WESTERN AND NORTHERN TERRITORIES}

SUMMARY This paper analyses the issue of memory related to Polish Eastern Borderlands based on the example of two cities located in different regions: Kwidzyn (located in the region of Powiśle) and Żary (located in the region of Lower Lusatia). An important aspect of the forming of this memory is not only the fact that those regions are a part of Polish Western and Northern Territories. The paper focuses on the dynamics of memory transformation related to this narrative, in regard to both witnesses of history and the post-memory of the area. After the end of World War II, Żary and Kwidzyn developed differently. The differences the authors consider especially significant are the varying structure of migration and the development and institutionalisation of the organisations in the Borderlands. Nevertheless, it is possible to identify some common characteristics in the development of the organizations of the Borderlands and to cautiously determine a common denominator.

\section{KEYWORDS}

POLISH WESTERN AND NORTHERN TERRITORIES, POLISH EASTERN BORDERLANDS, KWIDZYN, ŻARY, SOCIAL MEMORY FIELD 